\title{
Toward Digital Citizenship: Examining Factors Affecting Participation and Involvement in the Internet Society among Higher Education Students
}

\author{
Abdulrahman Al-Zahrani ${ }^{1}$ \\ ${ }^{1}$ Department of Educational Technology, Faculty of Education, King Abdulaziz University, Saudi Arabia \\ Correspondence: Abdulrahman Al-Zahrani, Department of Educational Technology, Faculty of Education, King \\ Abdulaziz University, P.O. Box 15758, Jeddah 21454, Saudi Arabia. Tel: 96-655-755-5571. E-mail: \\ ammz2@hotmail.com
}

Received: May 30, 2015 Accepted: July 5, 2015 Online Published: November 26, 2015

doi:10.5539/ies.v8n12p203 URL: http://dx.doi.org/10.5539/ies.v8n12p203

\begin{abstract}
The current study aims to understand digital citizenship, based on the assumptions of Ribble (2014), by examining factors affecting participation and involvement in the Internet virtual societies among higher education students. A quantitative approach using a survey questionnaire was implemented. The participants were 174 students from the Faculty of Education at King Abdulaziz University in Saudi Arabia. The descriptive statistics show that the students generally have good levels of perceived Internet attitude, computer self-efficacy, and digital citizenship, especially in terms of respecting oneself and others online. The factors affecting digital citizenship are computer experience, daily average technology use, students' attitudes toward the Internet, and computer self-efficacy. Students with higher levels of computer experience are more involved in activities related to educating oneself and connecting with others online compared with students with less experience. Further, students with higher levels of daily average technology use tend to protect themselves and others online more compared with students with lower levels of technology use. Moreover, higher levels of students' Internet attitude and computer self-efficacy are associated with higher levels of respect for oneself and others, of educating oneself and others, and of total digital citizenship. Based on the current study findings, appropriate recommendations are proposed in terms of policy and practice.
\end{abstract}

Keywords: digital citizenship, computer expertise, internet attitude, computer self-efficacy, Saudi Arabia

\section{Introduction}

Learners in the 21 st century are largely exposed to powerful online communication platforms such as social networking tools. These platforms can provide knowledge, information, and effective insights about rights, responsibilities, citizenship, and duties relevant to the 21st century (Langran \& Beishembaeva, 2011; E. Simsek \& A. Simsek, 2013). In essence, the concept of citizenship has shifted in societies. Individuals are now in charge of defining their own ethical characteristics (Bennett, 2008).

With the rapid development of technology, young people can be vulnerable to the misuse of technology (Miles, 2011). Current young learners can be easily exposed to violence, racism, information security and identity theft (Van Fossen \& Berson, 2008). This is because digital social networking tools "feature heavily distributed content, making it very difficult to control" (Richards, 2010, p. 520). Consequently, teenagers may experience emotional and psychological dangers including "their perceived anonymity, their accumulated digital portfolio or digital footprint, and the legal implications of thoughtless or malicious actions" (Oxley, 2011, p. 2).

A promising concept that initially aims to deal with the dilemma of cyber safety is digital citizenship. A significant effort toward promoting digital citizenship is the work of Mike Ribble. According to Ribble (2014), digital citizenship has three main themes: Respect, Educate, and Protect (REPs). Each theme has three basic elements that explain the appropriate behavior in digital environments, as shown in Table 1. 
Table 1. Main themes and elements of digital citizenship (Ribble, 2014)

\begin{tabular}{|c|c|}
\hline Themes & Elements \\
\hline \multirow{3}{*}{$\begin{array}{l}\text { Respect } \\
\text { (Yourself/Respect Others) }\end{array}$} & - Etiquette (electronic standards of conduct or procedure) \\
\hline & - Access (full electronic participation in society) \\
\hline & - Law (electronic responsibility for actions and deeds) \\
\hline \multirow{3}{*}{$\begin{array}{l}\text { Educate } \\
\text { (Yourself/Connect } \\
\text { Others) }\end{array}$} & - Communication (electronic exchange of information) \\
\hline & $\begin{array}{l}\text { - Literacy (process of teaching and learning about technology and the use of } \\
\text { technology) }\end{array}$ \\
\hline & - Commerce (electronic buying and selling of goods) \\
\hline \multirow{3}{*}{$\begin{array}{l}\text { Protect } \\
\text { (Yourself/Protect Others) }\end{array}$} & $\begin{array}{l}\text { - Rights and Responsibility (those freedoms extended to everyone in a digital } \\
\text { world) }\end{array}$ \\
\hline & - Safety (electronic precautions to guarantee safety) \\
\hline & $\begin{array}{l}\text { - Health and Welfare (physical and psychological well-being in a digital } \\
\text { technology world) }\end{array}$ \\
\hline
\end{tabular}

In Saudi Arabia, it seems that the issue of digital citizenship is more problematic. Surrounded by many factors such as cultural-religious domination, centralization and the strong tendency toward conservatism, the case of preserving Saudi identity in this fast-changing digital world is challenging. However, Saudi Arabia is a rapidly developing state that has willingly participated in global digital developments. This is largely linked with economic rapid growth that reflects the wide consumption of technology (Onsman, 2011). In this regard, Onsman (2011) argued that "ultimately, international competitiveness is likely to impact significantly and possibly irrevocably on Saudi cultural traditions and religion norms" (p. 1). Accordingly, the current research aims to understand students' digital citizenship in higher education as well as to investigate factors that may influence their digital behaviors in the context of Saudi Arabia, which can be sometimes problematic to understand and in many cases hard to predict.

\subsection{The Landscape of Digital Citizenship}

Digital citizenship refers to "the norms of appropriate, responsible behavior with regard to technology use" (Ribble, 2014). Miles (2011, pp. 1-2) defined it as "a sensible and reasonable approach to online interaction." Another definition was provided by Farmer (2011), who defined it as "the ability to use technology safely, responsibly, critically, productively, and civically" (p. 292). Digital citizenship advocates "the appropriate use of technologies in social contexts, including educational contexts" (Nosko \& Wood, 2011, p. 406). This concept has the core objective of helping young generations to make wise and reasonable choices in various digital settings and situations (Farmer, 2011; Hollandsworth, Dowdy, \& Donovan, 2011; Kassam, 2013; Roh, 2004; Miles, 2011; Ribble, 2014). Simply put, it is the new code of civil rights for the current digital learners (B. Sutton, V. Sutton, \& Plants, 2012).

In view of this, it can be argued that education can be the most effective way to protect students from risks associated with online participation (Binkley et al., 2012; Farmer, 2011; Hollandsworth et al., 2011; Ohler, 2010, 2011; Oxley, 2011; Ribble, 2012; Richards, 2010; Roh, 2004; Van Fossen \& Berson, 2008; Zwart, Lindsay, Henderson, \& Phillips, 2011). Given the importance of digital citizenship education, Hollandsworth et al. (2011) stated, "The growing level of Internet access and student use, both in and out of school, raises the question, who will own this challenge of guiding students toward a productive and safe technological society?" (p. 38). A promising answer is provided by Nosko and Wood (2011), who emphasized that the development of digital citizenship requires effective collaboration between educators, students and the whole educational system to formulate effective codes of conduct and to facilitate culturally appropriate behaviors online.

One significant duty of 21 st century educators is to teach current learners about cyber safety in order to address and prevent technology misuse (Farmer, 2011; Oxley, 2011; Van Fossen \& Berson, 2008). Oxley (2011) argued that it is critical to educate youth about the risks related to inappropriate or unethical use of technology, especially the Internet. To do so, it is important to have specifically tailored educational activities that focus on providing necessary skills and relevant information about risks associated with digital technologies (Van Fossen \& Berson, 2008; Zwart et al., 2011). Through education, new skills that meet the demands of the 21st century should substitute the basic skills and knowledge of the past (Binkley et al., 2012; Chee, Mehrotra, \& Liu, 2013; 
Larson \& Miller, 2011; Ribble, 2012). Hollandsworth et al. (2011) concluded that if the current educational paradigms do not respond to these issues, "the digital culture establishes its own direction, potentially pushing a productive, long-term solution further out of reach" (p. 37). However, teaching digital citizenship is not an easy mission. It can be puzzling, considering the prevailing traditional paradigms in education (Chee et al., 2013; Nosko \& Wood, 2011; Ohler, 2011; Ribble, 2012; Sutton et al., 2012). Another associated problem is that educators usually perceive digital citizenship as a "technology problem rather than a societal issue that affects everyone" (Ribble, 2012, p. 149).

The emerging digital citizenship has gained increasing global attention. International organizations interested in promoting meaningful learning that is more relevant to the digital era are in a race to encourage safer cyber participation. For instance, the most recent technology standards for students developed by the International Society for Technology in Education (ISTE) contained a major category about digital citizenship. Under this category, the standards are: (a) to advocate and practice safe, legal, and responsible use of information and technology; (b) to exhibit a positive attitude toward using technology that supports collaboration, learning, and productivity; (c) to demonstrate personal responsibility for lifelong learning; and (d) to exhibit leadership for digital citizenship (ISTE, 2007).

\subsection{Factors Influencing Digital Citizenship}

The current study hypotheses that digital citizenship, as an expectation of everyday life digital routine, can be influenced by the individuals' attitudes toward the Internet, the way they trust their technological abilities (self-efficacy) as well as their computer expertise. For more illustration, see Figure 1.

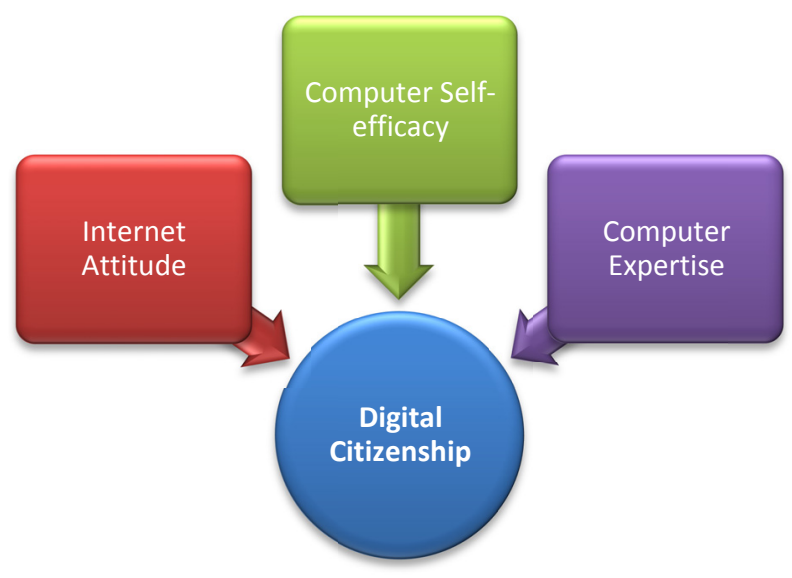

Figure 1. Factors influence digital citizenship

For instance, students' attitudes toward computers and technology play a core mission in the promotion of digital citizenship (ISTE, 2007). A positive relationship between technology attitudes and digital citizenship was suggested in the work of Shelley et al. (2004), who found a direct linkage between technology attitudes and digital citizenship that could help bridge the gap in the digital divide in the United States. In this regard, E. Simsek and A. Simsek (2013) argued: "People became addicted to information. Readers, as the audience, have become digital users. Information processing has been transformed from being passive receivers to active information processors, who must engage, construct, respond, and act with information" (p. 127). Therefore, enhancing learners' attitudes toward computers and technology should be a continuous process if technology is to be used in teaching and learning approaches (Sam, Othman, \& Nordin, 2005).

Another factor that seems to have earned little attention in the existing literature and may have an impact on digital citizenship is the learners' computer self-efficacy. Self-efficacy is defined as the individual's judgement of his or her ability to execute a certain and conditioned course of behavior/s or to complete specified tasks (Bandura, 1997). Differences in self-efficacy levels occur depending on several key questions, including the way individuals construe themselves, the attributes they think they possess, the roles they presume they are expected to play, the capabilities they believe they have acquired, the views they share with others, and their judgment of how they are viewed by others (Bong \& Skaalvik, 2003). Wangpipatwong, Chutimaskul, and Papasratorn, (2008) conducted a study to identify factors influencing digital citizens' intention to use e-government websites. The 
results showed that computer self-efficacy is positively correlated with the intention to use e-government services and effectively participate in virtual environments.

A third potential factor that the current study aims to investigate is computer expertise, in terms of computer qualifications, computer experience, and daily average computer use. The role of computer expertise in promoting high levels of computer efficiency, especially in education, is well documented in the literature. With the wide expansion of technology use in today's societies, "students need increased expertise in digital technologies" (Larson \& Miller, 2011, p. 122). In this regard, Vannatta (2007) argued that "technology skills and fluency are essential to using technology" (p. 136). Bahr, Shaha, Farnsworth, Lewis, and Benson (2004) stated that it is widely acknowledged that increased skills and knowledge about technology through practice are interrelated with increased motivation and willingness to use technology. As Georgina and Hosford (2009) found, the relationship between technology literacy and practice is significantly mutual. However, there is lesser evidence with regard to the impact of computer expertise on digital citizenship. This impact is what the current study intends to explore.

\section{Research Problem}

Although digital citizenship may be part of the equation toward achieving effective use of technology and lessening its negative effects, efforts to control the risks associated with digital technologies are "fraught with difficulties" and still long overdue (Van Fossen \& Berson, 2008, p. 122). Besides, the existing literature gives little focus to factors that may affect digital citizenship. In the context of Saudi Arabia, there is a clear absent of authentic research devoted for understanding digital citizenship, especially among higher education students.

\section{Research Aim and Key Questions}

The current study, therefore, aims to understand digital citizenship, as well as identify factors that may lead to the development of higher education students' digital characteristics. The current study adopts the theoretical framework of Ribble (2014). The following research questions guide the study:

- What is the level of students' digital citizenship in terms of REPs?

- Does computer expertise (experience, daily average use, and qualifications) impact students' digital citizenship in terms of REPs?

- Does students' Internet attitude impact their digital citizenship in terms of REPs?

- Does students' perceived computer self-efficacy impact their digital citizenship in terms of REPs?

\section{Methodology}

To answer the research questions, a quantitative approach was implemented using survey questionnaire to collect the data.

\subsection{Sampling}

The strategy used in the current study is probability sampling, in which there is a possibility for every member of the population to participate (Mertens, 2005). Thus, probability sampling allows a random convenience sample to take part in the study (Mertens, 2005).

The context was the Faculty of Education at King Abdulaziz University. More than 250 students showed willingness to participate in the current study, which used the snowball technique to recruit respondents (Mertens, 2005). A total of 213 completed questionnaires were collected and checked after the deadline for submission. After excluding those with more than 85 percent incomplete data, the final number of useable questionnaires was 174 , yielding a return rate of about 82 percent.

\subsection{Questionnaire Design}

The questionnaire included two major sections: (a) general information and (b) digital citizenship. A five-point Likert scale $(5=$ strongly agree, $1=$ strongly disagree) was used to classify the students' responses. The first section aimed to collect general information and respondents' perception on the possible factors that may impact students' digital citizenship. It gathered information on students' computer experience, daily average computer use, and computer qualifications (computer expertise). It also investigated two technology-related perceptions: Internet attitude and computer self-efficacy.

The scale used for Internet attitude was a modified version of Sam et al. (2005) who originally adapted the Computer Attitude Scale that has 20-item, developed and validated by Nickell and Pinto (1986). The internet attitude scale in the current study has only 10 items (see Appendix 1). For computer self-efficacy, the scale was originally designed for the current study; this scale consists of 18 items (see Appendix 2). 
The digital citizenship scale in the second section was specifically designed for the current study based on the assumptions of Ribble (2014). It includes 46 items categorized in three main sections (Subscales), which intended to meet the three main themes of REPs (see Appendix 3). The number of items included in each subscale is presented in Table 2.

Table 2. Digital citizenship scale (REPs)

\begin{tabular}{ll}
\hline Subscale & $\mathrm{N}$ \\
\hline Respect Yourself/Respect Others & 24 \\
Educate Yourself/Connect with Others & 11 \\
Protect Yourself/Protect Others & 11 \\
Total & 46 \\
\hline
\end{tabular}

\subsection{Validity and Reliability}

The vast majority of the participants spoke the Arabic language. Therefore, the questionnaires were first developed in English and subsequently translated into Arabic before distribution. Because the Arabic language is the researcher's mother tongue, the researcher himself translated the questionnaire to ensure its accuracy. According to Mertens (2005), "because survey research uses decontextualized words through its very nature, the researcher must be careful to interpret the words in light of the particular cultural circumstances" (p. 185). Hence, three specialists and Arabic native speakers reviewed the translation to ensure its accuracy and clarity.

The questionnaire validity was tested by having a panel of experts check its relevance, content, and construction (Mertens, 2005). Based on these experts' opinions, necessary and appropriate changes were made. Reliability statistics obtained using Cronbach's alpha coefficient indicated acceptable internal consistency levels exceeding .7 (Pallant, 2007). See Table 3.

Table 3. Reliability statistics

\begin{tabular}{llll}
\hline & Subscale & $\alpha$ & N \\
\hline \multirow{2}{*}{ Attitude and Self-efficacy } & Attitude & .71 & 10 \\
& Self-efficacy & .93 & 18 \\
& Respect Yourself/Respect Others & 90 & 24 \\
Digital Citizenship & Educate Yourself/Connect with Others & .88 & 11 \\
& Protect Yourself/Protect Others & .83 & 11 \\
& Total Digital Citizenship & .89 & 46 \\
Total Questionnaire & & 92 & 74 \\
\hline
\end{tabular}

\section{Results}

\subsection{Students' Computer Expertise}

Investigating the students' technological expertise included determining their computer experience, daily average computer use, and computer qualifications (see Table 4). 
Table 4. Students' computer expertise $(\mathrm{n}=174)$

\begin{tabular}{llcccc}
\hline Computer Expertise & Group & $\mathrm{N}$ & $\%$ & $M$ & $S D$ \\
\hline \multirow{3}{*}{ Computer Experience } & Less than 5 Years & 70 & 40.2 & & \\
& From 5 to 10 Years & 95 & 54.6 & 1.65 & 0.58 \\
& More than 10 Years & 9 & 5.2 & & \\
Daily Average Computer Use & Less than 1 Hour & 36 & 20.7 & & \\
& From 1 to 5 Hours & 118 & 67.8 & 1.91 & 0.56 \\
& More than 5 Hours & 20 & 11.5 & & \\
Computer Qualifications & No Qualifications & 121 & 69.5 & \multirow{2}{*}{1.30} & 0.46 \\
& Short Courses & 53 & 30.5 & & \\
\hline
\end{tabular}

The data in Table 4 show that most of the students have an average computer experience of between 5 to 10 years. Although most of the students have no computer qualifications, they reported a high daily average use of 5 hours or more.

\subsection{Students' Internet Attitude and Computer Self-Efficacy}

To gain a general picture of the students' Internet attitude, the total mean of their responses was calculated (see Table 5).

Table 5. Attitude and computer self-efficacy $(\mathrm{n}=174)$

\begin{tabular}{lcl}
\hline Scale & $M$ & $S D$ \\
\hline Total Attitude & 4.52 & 0.36 \\
Total Computer Self-efficacy & 4.10 & 0.66 \\
\hline
\end{tabular}

As shown in Table 5, the total mean indicates that the students have very good levels of perceived Internet attitude $(M=4.52)$. The data also show that the students tend to have a good level of computer self-efficacy ( $M=$ 4.10) and that they trust their abilities to deal with computer technology and implement it to satisfy their needs.

\subsection{Students' Digital Citizenship}

One of the main purposes of the current study is to understand students' digital citizenship. As previously discussed, the digital citizenship scale was divided into three subscales. The total mean score for each subscale, as well as the total mean for the scale, are shown in Table 6.

Table 6. Digital citizenship $(\mathrm{n}=174)$

\begin{tabular}{lll}
\hline Subscale & $M$ & $S D$ \\
\hline Total Educate Yourself/Connect with Others & 3.61 & 0.78 \\
Total Protect Yourself/Protect Others & 3.63 & 0.78 \\
Total Respect Yourself/Respect Others & 4.37 & 0.51 \\
Total Digital Citizenship & 4.01 & 0.43 \\
\hline
\end{tabular}

Based on the data in Table 6, the total mean for students' digital citizenship is 4.01, which indicates good levels. However, the digital citizenship practices with the highest mean are those concerning respect for oneself and others $(M=4.37)$. This is followed by practices with regard to protecting oneself and others $(M=3.63)$ and educating oneself/connecting with others $(M=3.61)$, which showed similar results.

\subsection{Students' Computer Expertise Influences Digital Citizenship}

A one-way between-groups multivariate analysis of variance (MANOVA) was performed to investigate the impact of the students' computer expertise, which includes their computer experience, daily average computer 
use, and computer qualifications as dependent variables, on their digital citizenship (independent variable). Preliminary assumption testing was conducted to check the sample distribution, linearity, normality, multicolinearity, univariate and multivariate outliers, and homogeneity of variance-covariance with no serious violations noted. Accordingly, Wilks' lambda values $(\lambda)$ are shown in Table 7.

Table 7. Impact of computer expertise on students' digital citizenship (MANOVA)

\begin{tabular}{lllllll}
\hline Effect & Wilks' $\lambda$ & F & Hypothesis df & Error df & Sig. & partial $\eta^{2}$ \\
\hline Computer Experience & .88 & 3.38 & 6 & 314 & .003 & .088 \\
Daily Average Computer Use & .88 & 3.39 & 6 & 314 & .003 & .083 \\
Computer Qualifications & .97 & 1.61 & 3 & 157 & .190 & .056 \\
\hline
\end{tabular}

The MANOVA results indicate a statistically significant impact of the students' computer expertise on their digital citizenship, as follows:

- $\quad$ Computer experience $[F(6,314)=3.38, p=.003$; Wilks' $\lambda=.88$; partial eta squared $=.088]$.

- $\quad$ Computer daily average use $\left[F(6,382)=3.39, p=.003\right.$; Wilks' $\lambda=.88$; partial $\left.\eta^{2}=.083\right]$.

Table 8 shows the impacts that reached statistical significance when the results for the dependent variables were considered separately.

Table 8. Test results for between-subjects effects

\begin{tabular}{|c|c|c|c|c|c|c|c|}
\hline Source & Dependent Variable & $\begin{array}{l}\text { Type } \\
\text { Sum } \\
\text { Squares }\end{array}$ & $\begin{array}{l}\text { III } \\
\text { of df }\end{array}$ & $\begin{array}{l}\text { Mean } \\
\text { Square }\end{array}$ & $\mathrm{F}$ & Sig. & partial $\eta 2$ \\
\hline $\begin{array}{l}\text { Computer } \\
\text { Experience }\end{array}$ & $\begin{array}{l}\text { Educate Yourself/ } \\
\text { Connect with Others }\end{array}$ & 6.97 & 2 & 3.48 & 7.85 & .001 & .090 \\
\hline $\begin{array}{l}\text { Daily Average } \\
\text { Computer Use }\end{array}$ & $\begin{array}{l}\text { Protect Yourself/ } \\
\text { Protect Others }\end{array}$ & 6.17 & 2 & 3.09 & 6.27 & .002 & .073 \\
\hline
\end{tabular}

Computer experience showed a statistically significant impact on students' digital participation in terms of educating oneself and connecting with others $[F(1,174)=7.85, p=.001$, partial $\eta 2=.090]$. An examination of the mean scores indicated that students with computer experience ranging from 5 to 10 years (the majority) were more involved in activities related to educating oneself and connecting with others $(M=4.04)$ compared with students with less than 5 years of computer experience $(M=3.65)$.

The students' daily average computer use was found to significantly impact practices with regard to protecting oneself and others $[F(1,174)=6.27, p=.002$, partial $\eta 2=.073]$. The mean differences show that students with the highest daily average computer use (more than 5 hours a day) tend to protect themselves and others in digital activities $(M=3.80)$ more compared with those with a daily average computer use of less than 1 hour $(M=3.18)$ or 1 to 5 hours $(M=3.73)$.

\subsection{Students' Attitudes and Self-Efficacy Impact Digital Citizenship}

By using Pearson's product-moment correlation coefficients, the relationships between the students' Internet attitude, computer self-efficacy, and digital citizenship were investigated, revealing six positive correlations (see Table 9). 
Table 9. Pearson's correlations for students' attitudes, self-efficacy, and digital citizenship

\begin{tabular}{llllll}
\hline & & $\begin{array}{l}\text { Respect } \\
\text { Yourself/Respect } \\
\text { Others }\end{array}$ & $\begin{array}{l}\text { Educate } \\
\text { Yourself/Connect } \\
\text { with Others }\end{array}$ & $\begin{array}{l}\text { Protect } \\
\text { Yourself/Protect } \\
\text { Others }\end{array}$ & $\begin{array}{l}\text { Total Digital } \\
\text { Citizenship }\end{array}$ \\
\hline Attitude & PC & $.354^{* *}$ & $.247^{* *}$ & .082 & $.363^{* *}$ \\
$(\mathrm{n}=174)$ & Sig. & .000 & .001 & .284 & .000 \\
Self-efficacy & PC & $.297^{* *}$ & $.367^{* *}$ & .147 & $.408^{* *}$ \\
$(\mathrm{n}=174)$ & Sig. & .000 & .000 & .053 & .000 \\
\hline
\end{tabular}

**: The correlation is significant at the 0.01 level (2-tailed); PC, Pearson correlation.

As the data in Table 9 suggest, higher levels of students' Internet attitude are associated with higher levels of respect for oneself and others online $[r=.354, n=174, p=.000]$. Also, higher levels of students' Internet attitude are strongly correlated with practices of educating oneself and others online $[r=.247, n=174, p=.001]$. The total digital citizenship is positively correlated with students' Internet attitude $[r=.363, n=174, p=.000]$. However, no correlation was found between students' Internet attitudes and practices toward protecting oneself and others online.

Similarly, higher levels of students' computer self-efficacy are associated with higher levels of respect for oneself and others online $[r=.297, n=174, p=.000]$. Further, higher levels of students' computer self-efficacy are positively correlated with the stance of educating oneself and others online $[r=.367, n=174, p=.000]$. Higher levels of students' computer self-efficacy are also strongly linked to higher levels of total digital citizenship $[r=.408, n=174, p=.000]$. Pearson's correlation coefficients suggest no relationship between students' computer self-efficacy and their practices of protecting oneself and others online.

\section{Discussion}

The background information revealed that most of the students have an average computer experience of between 5 to 10 years. Although most of the students have no computer qualification, they reported a high daily average use of five hours or more. This pattern mirrors the rapid increase in the use of technology as a global power.

The results also indicate that the students have good levels of perceived Internet attitude and computer self-efficacy. The students perceive the Internet as a useful tool for effective participation in the 21 st century. They themselves can be seen as motivated learners who generally trust their abilities to integrate technology into their daily lifestyles, including learning activities. This result also can be supported by the assumption found in the current study in which no connection was found between technology computer qualification and digital citizenship.

The students correspondingly showed good levels of digital citizenship, especially in terms of respecting oneself and others online. This, in particular, indicates that respect is a main issue for students engaged in virtual communities. Clearly, students prefer to participate in respectable, proper, and suitable online communities in which they feel respected and can show respect to others. It appears that students reject the notion of cyberbullying and believe in the importance of respecting others' identities, cultures, and human rights. The literature suggests that respect, especially for others, is vital in digital societies, "since it is becoming much easier to infringe others' rights due to the advances of ICTs" (Roh, 2004, p. 168). Respect has become a necessity for global learners in the 21st century, both in and out of the digital environment. Kassam (2013) argued that:

Much preparation for the social aspects of discussion, which include respect and responsibility for the welfare of all, the critical literacy required for the fast paced transparent and interactive world of the digital media, good responsible citizenship and the ability to discuss and argue with respect for everyone, are skills that can be taught in the classroom without the latest access to social networks in the Web 2.0 world. (p. 261).

Another interesting result is that students with higher levels of computer experience were found to be more involved in activities related to educating oneself and connecting with others online compared with students with less computer experience. Apparently, students with higher levels of computer experience tend to share their knowledge with others online and create more effective ways of communication. Computer experience seems to play a catalyst role in seeking and exchanging information with others online. 
Further, students with higher levels of daily average technology use tend to protect themselves and others in the digital environment more compared with students with lower daily average technology use. Security issues seem very important to students who use technology extensively on a daily basis. Therefore, it is important for them to protect themselves and share relevant information with others online.

The current study also found that higher levels of students' attitudes toward the Internet are associated with higher levels of respect for oneself and others, of educating oneself and others, and of total digital citizenship. The way students feel about the Internet and its implications appear to impact the way they perceive their digital identities. Students with good levels of attitudes toward the Internet can be better digital citizens who respect themselves and others and may effectively engage in more activities relevant to educating themselves and others online. This result is consistent with those of Shelley et al. (2004), who found a direct connection between students' attitudes toward technology and digital citizenship.

Similarly, higher levels of students' computer self-efficacy are associated with higher levels of respect for oneself and others, of educating oneself and others, and of total digital citizenship. This result suggests that students' higher levels of confidence with regard to computers and technology use can motivate higher levels of digital citizenship. Students who feel confident of and trust their technological abilities tend to respect themselves and others online. Being confident and motivated, they like to learn and share information in respectable virtual environments. These results support the findings of Wangpipatwong et al. (2008), which showed that computer self-efficacy has a positive impact on participants' intention to participate in the internet virtual societies' such as the e-government websites.

\section{Conclusions and Implications}

The current study aimed to understand students' digital citizenship and the possible factors that may impact it. A quantitative approach using a survey questionnaire was implemented. The participants were 174 students from the Faculty of Education at King Abdulaziz University in Saudi Arabia. The findings indicate that the students have acceptable levels of perceived Internet attitude and computer self-efficacy. The students also showed good levels of digital citizenship, especially in terms of respecting oneself and others online. Technology expertise, in terms of computer experience and daily average technology use, despite computer qualifications, is suggested to be positively correlated with digital citizenship. Also, the students' attitudes toward the Internet and their computer self-efficacy may positively impact their digital citizenship, especially with regard to respecting and educating oneself and others online.

A limitation of the present study is that its results are based on a survey conducted in Saudi Arabia and thus may not be generalizable to other parts of the world. However, the findings may provide insights for future research on digital citizenship and the factors that contribute to the enhancement of 21 st century learners' digital behaviors. Hence, it can be argued that the current study findings reflects the practices of digital citizenship in mono-cultural and conservative nations, such as Saudi Arabia.

The results of this research have several potential implications relevant to policy and practice, especially for developing countries such as Saudi Arabia. It is important to establish appropriate policies for digital practices in higher education. These policies should have the core mission not only of explaining what, when, and how to effectively use technology but also of illustrating the norms and principles of digital citizenship. Policies should also work toward raising awareness about digital citizenship as a global demand that is not limited to a specific context or domain. They should also contribute to the enhancement of digital citizenship through the promotion of respect for other cultures and digital identities.

Because it is critical for students to be good digital citizens and to use technology responsibly, it is necessary to enhance their levels of Internet attitude and perceived computer self-efficacy. This can be achieved through digital citizenship education, in which students should be provided with relevant literacy and practice to foster their self-confidence and positive attitudes toward digital technologies, especially the Internet. Curricula as well should have embedded technology-based practices to enhance students' technological expertise and facilitate the appropriate use of technology as an effective learning tool.

\section{References}

Bahr, D. L., Shaha, S. H., Farnsworth, B. J., Lewis, V. K., \& Benson, L. F. (2004). Preparing tomorrow's teachers to use technology: Attitudinal impacts of technology-supported field experience on pre-service teacher candidates. Journal of Instructional Psychology, 31(2), 88-97.

Bandura, A. (1997). Self-efficacy: The Exercise of Control. New York: NY: W. H. Free man.

Bennett, W. L. (2008). Changing citizenship in the digital age. In W. L. Bennett (Ed.), Civic life online (pp. 1-24). 
Cambridge, MA: MIT Press.

Binkley, M., Erstad, O., Herman, J., Raizen, S., Ripley, M., Miller-Ricci, M., \& Rumble, M. (2012). Defining Twenty-First Century Skills. In P. Griffin, B. McGaw, \& E. Care (Eds.), Assessment and Teaching of 21 st Century Skills (pp. 17-66). Springer Netherlands. http://dx.doi.org/10.1007/978-94-007-2324-5_2

Bong, M., \& Skaalvik, E. M. (2003). Academic self-concept and self-efficacy: How different are they really? Educational Psychology Review, 15(1), 1-40. http://dx.doi.org/10.1023/A:1021302408382

Chee, Y. S., Mehrotra, S., \& Liu, Q. (2013). Effective game based citizenship education in the age of new media. The Electronic Journal of e-Learning, 11(1), 16-28.

Farmer, L. (2011). Teaching digital citizenship. Paper presented at the Global TIME 2011. Retrieved from http://www.editlib.org/p/37093

Georgina, D. A., \& Hosford, C. C. (2009). Higher education faculty perceptions on technology integration and training. Teaching and Teacher Education, 25(5), 690-696. http://dx.doi.org/10.1016/j.tate.2008.11.004

Hollandsworth, R., Dowdy, L., \& Donovan, J. (2011). Digital citizenship in K-12: It takes a village. TechTrends, 55(4), 37-47. http://dx.doi.org/10.1007/s11528-011-0510-z

ISTE. (2007). National educational technology standards projects. International Society for Technology in Education. Retrieved May 14, 2015, from http://www.iste.org/standards/iste-standards/standards-forstudents

Kassam, A. (2013). Changing society using new technologies: Youth participation in the social media revolution and its implications for the development of democracy in sub-Saharan Africa. Education and Information Technologies, 18(2), 253-263. http://dx.doi.org/10.1007/s10639-012-9229-5

Langran, E., \& Beishembaeva, A. (2011). Teaching for global citizenship with geospatial technology. Paper presented at the Society for Information Technology \& Teacher Education International Conference 2011, Nashville, Tennessee, USA. Retrieved from http://www.editlib.org/p/36928

Larsen, E., \& Rainie, L. (2002). The rise of the e-citizen: How people use government agencies' web sites. Retrieved June 17, 2014, from http://www.pewinternet.org/files/old-media//Files/Reports/2002/PIP_Govt_ Website_Rpt.pdf.pdf

Larson, L. C., \& Miller, T. N. (2011). $21^{\text {st }}$ century skills: Prepare students for the future. Kappa Delta Pi Record, 47(3), 121-123. http://dx.doi.org/10.1080/00228958.2011.10516575

Mertens, D. M. (2005). Research and Evaluation in Education and Psychology: Integrating Diversity with Quantitative, Qualitative, and Mixed Methods (2nd ed.). Thousand Oaks, Calif., London: Sage Publications.

Miles, D. (2011). Youth protection: Digital citizenship-Principles and new resources. Paper presented at the Cybersecurity Summit (WCS), 2011 Second Worldwide.

Nickell, G. S., \& Pinto, J. N. (1986). The computer attitude scale. Computers in Human Behavior, 2, 301-306. http://dx.doi.org/10.1016/0747-5632(86)90010-5

Nosko, A., \& Wood, E. (2011). Learning in the Digital Age with SNSs: Creating a Profile. In B. White, I. King, \& P. Tsang (Eds.), Social Media Tools and Platforms in Learning Environments (pp. 399-418). Springer Berlin Heidelberg. Retrieved from http://dx.doi.org/10.1007/978-3-642-20392-3_24

Ohler, J. (2011). Digital citizenship means character education for the digital age. Kappa Delta Pi Record, 47(Sup1), 25-27. http://dx.doi.org/10.1080/00228958.2011.10516720

Ohler, J. B. (2010). Digital Community, Digital Citizen. Corwin Press. Thousand Oaks, CA: Corwin Press.

Onsman, A. (2011). It is better to light a candle than to ban the darkness: Government led academic development in Saudi Arabian universities. Higher Education, 1-14. http://dx.doi.org/10.1007/s10734-010-9402-y

Oxley, C. (2011). Digital citizenship: Developing an ethical and responsible online culture. Access, 25(3), 5-9.

Pallant, J. F. (2007). SPSS Survival Manual: A Step By Step Guide To Data Analysis Using SPSS (3rd ed.). Crows Nest, NSW: Allen \& Unwin.

Ribble, M. (2012). Digital citizenship for educational change. Kappa Delta Pi Record, 48(4), 148-151. http://dx.doi.org/10.1080/00228958.2012.734015

Ribble, M. (2014). Digital Citizenship: Using Technology Appropriately. Retrieved February 13, 2014, from http://digitalcitizenship.net/Home_Page.html 
Richards, R. (2010). Digital citizenship and web 2.0 tools. MERLOT Journal of Online Learning and Teaching, $6(2), 516-522$.

Roh, Y.-R. (2004). Democratic citizenship education in the information age: A comparative study of South Korea and Australia. Asia Pacific Education Review, 5(2), 167-177. http://dx.doi.org/10.1007/BF03024954

Sam, H. K., Othman, A. E. A., \& Nordin, Z. S. (2005). Computer self-efficacy, computer anxiety, and attitudes toward the internet: A study among undergraduates in Unimas. Educational Technology \& Society, 8(4), 205-219.

Shelley, M., Thrane, L., Shulman, S., Lang, E., Beisser, S., Larson, T., \& Mutiti, J. (2004). Digital citizenship: Parameters of the digital divide. Social Science Computer Review, 22(2), 256-269. http://dx.doi.org/10.1177/0894439303262580

Simsek, E., \& Simsek, A. (2013). New literacies for digital citizenship. Contemporary Educational Technology, 4(2), 126-137.

Sutton, B., Sutton, V., \& Plants, B. (2012). Digital Citizenship. Paper presented at the Society for Information Technology \& Teacher Education International Conference 2012, Austin, Texas, USA. Retrieved from http://www.editlib.org/p/39818

VanFossen, P. J., \& Berson, M. J. (2008). Civic literacy in a digital age. Contemporary Issues in Technology and Teacher Education, 8(2), 122-124.

Vannatta, R. (2007). The Intrepid Explorer: A Model of Effective Technology Use for All Educators. In K. Kumpulainen (Ed.), Educational Technology: Opportunities and Challenges. Finland: OULU University Press, OULU 2007.

Wangpipatwong, S., Chutimaskul, W., \& Papasratorn, B. (2008). Understanding citizen's continuance intention to use e-government website: A composite view of technology acceptance model and computer self-efficacy. Electronic Journal of e-Government Volume, 6(1), 55-64.

Winn, J. (2006). Global Citizenship: An unintended consequence of information literacy instruction for graduate teacher education students. Paper presented at the Society for Information Technology \& Teacher Education International Conference 2006, Orlando, Florida, USA. http://www.editlib.org/p/22149

Zwart, M. d., Lindsay, D., Henderson, M., \& Phillips, M. (2011). Teenagers, Legal Risks and Social Networking Sites. Victoria, Australia: Monash University.

\section{Appendix 1}

\section{Internet Attitudes Scale}

\begin{tabular}{|c|c|c|c|c|c|}
\hline Items & SA & A & $\mathrm{N}$ & $\mathrm{D}$ & SD \\
\hline 1. The Internet makes me comfortable because I understand it & & & & & \\
\hline 2. The Internet is responsible for many good things we enjoy & & & & & \\
\hline $\begin{array}{l}\text { 3. There are unlimited possibilities of Internet applications that have not been } \\
\text { thought of yet }\end{array}$ & & & & & \\
\hline 4. The reasonable use of the Internet can be very useful to humans & & & & & \\
\hline 5. The Internet can eliminate a lot of tedious work & & & & & \\
\hline 6. The use of the Internet is enhancing our standard of living & & & & & \\
\hline 7. The Internet is bringing us into a bright new era & & & & & \\
\hline
\end{tabular}


8. Life will be easier and faster with the Internet

9. The Internet provides easy, rich and enjoyable source of information

10. Life will be much easier with the Internet

\section{Appendix 2}

\section{Computer Self-Efficacy Scale}

(I feel Confident ...)

1. working on a personal computer

2. installing and uninstalling any program (software)

3. entering and saving data (numbers and words) into a file

4. opining and escaping (exiting) from the program (software)

5. calling up a data fie to view on the monitor screen

6. understanding terms/ words relating to computer hardware

7. understanding terms/words relating to computer software

8. learning advanced skills within a specific program (software)

9. using a printer to make "hardcopy" of my work

10. copying a disc

11. adding and deleting information from a data file

12. using the computer to write a letter, essay or assignment

13. describing the function of computer hardware (e.g. keyboard, monitor, disc drives, computer processing unit)

14. understanding the 3 stages of data processing: input, processing, output

15. getting help for problems in the computer system

16. using the computer to organize information

17. getting rid of files when they are no longer needed 
18. troubleshooting computer problems

\section{Appendix 3}

\section{Digital Citizenship Scale}

\begin{tabular}{|c|c|}
\hline Subscale & Item \\
\hline \multirow{7}{*}{$\begin{array}{l}\text { Respect Yourself/ } \\
\text { Respect Others } \\
(\mathrm{N}=24)\end{array}$} & $\begin{array}{l}\text { 1. I believe that everyone has basic digital rights, such as privacy and the right of } \\
\text { expression and speech. }\end{array}$ \\
\hline & $\begin{array}{l}\text { 2. I believe that basic digital rights must be addressed, discussed, and understood by } \\
\text { digital technology users. }\end{array}$ \\
\hline & 3. I need to be taught about the inherent dangers of overuse of digital technologies. \\
\hline & $\begin{array}{l}\text { 4. I believe that creating destructive worms or viruses, creating Trojan Horses, and } \\
\text { sending spam are digital crimes. }\end{array}$ \\
\hline & $\begin{array}{l}\text { 5. I understand the health and well-being risks surrounding the overuse of digital } \\
\text { technologies, such as addiction and stress. }\end{array}$ \\
\hline & $\begin{array}{l}\text { 6. I believe that hacking into others' information, downloading illegal music and movies, } \\
\text { plagiarizing, or stealing anyone's identification or property is unethical. }\end{array}$ \\
\hline & 7. In an online digital environment, I always respect others' opinion and knowledge. \\
\hline \multirow{7}{*}{$\begin{array}{c}\text { - Etiquette } \\
\text { - Access } \\
\text { - Law }\end{array}$} & 8. In an online digital environment, I always respect others' feelings. \\
\hline & $\begin{array}{l}\text { 9. In an online digital environment, I always make sure not to interrupt others when it is } \\
\text { their turn. }\end{array}$ \\
\hline & $\begin{array}{l}\text { 10. I believe that digital technology users also have responsibilities, such as respecting } \\
\text { others' basic digital rights. }\end{array}$ \\
\hline & 11. I immediately delete emails from a suspicious source or sender. \\
\hline & $\begin{array}{l}\text { 12. When I feel unhappy or uncomfortable in an online digital environment, I try to } \\
\text { express my feelings in a very rational way. }\end{array}$ \\
\hline & 13. I use email service to communicate with others \\
\hline & $\begin{array}{l}\text { 14. I believe in the importance of maintaining good physical and psychological health in } \\
\text { this digital world. }\end{array}$ \\
\hline
\end{tabular}




\begin{tabular}{|c|c|}
\hline Subscale & Item \\
\hline & 15. I do not save any important information on public computers. \\
\hline & $\begin{array}{l}\text { 16. I believe that understanding digital rights and responsibilities helps everyone to be } \\
\text { productive. }\end{array}$ \\
\hline & 17. I believe that everyone should take responsibility for his/her online actions and deeds. \\
\hline & $\begin{array}{l}\text { 18. I believe that the use of digital technologies must be a compromise between the } \\
\text { earrings and negligence. }\end{array}$ \\
\hline & $\begin{array}{l}\text { 19. Digital communication tools allow me to build new friendships in other parts of the } \\
\text { world. }\end{array}$ \\
\hline & 20. I have antivirus and Internet security protection on my computer. \\
\hline & $\begin{array}{l}\text { 21. I do not provide any unknown online parties with my personal information, such as } \\
\text { bank accounts or credit cards. }\end{array}$ \\
\hline & $\begin{array}{l}\text { 22. In digital communication, I respect others' human rights, cultures, and right to } \\
\text { expression. }\end{array}$ \\
\hline & 23. Digital communication tools allow me to communicate with my friends easily. \\
\hline & $\begin{array}{l}\text { 24. In an online digital environment, I try to make sure that everyone has an equal } \\
\text { opportunity for speech and discussion. }\end{array}$ \\
\hline \multirow{5}{*}{$\begin{array}{c}\text { Educate Yourself/ } \\
\text { Connect with } \\
\text { Others } \\
(\mathrm{N}=11)\end{array}$} & 25. Electronic commerce gives me better choices. \\
\hline & 26. Electronic commerce gives me more reasonable prices. \\
\hline & 27. I always buy legal goods. \\
\hline & 28. I do some research before buying anything from online stores. \\
\hline & 29. Electronic commerce does not conflict with my society's regulations. \\
\hline \multirow{4}{*}{$\begin{array}{c}\text { - Communication } \\
\text { - Literacy } \\
\text { - Commerce }\end{array}$} & 30. I love using electronic commerce tools (e.g., eBay \& Amazon). \\
\hline & 31. I prefer electronic commerce over going to the market. \\
\hline & 32. I spend some time on social networks, such as Facebook and Twitter. \\
\hline & 33. I use digital communication to express my opinion, learn, and share expertise. \\
\hline
\end{tabular}




\begin{tabular}{|c|c|}
\hline Subscale & Item \\
\hline & $\begin{array}{l}\text { 34. I have been taught the new educational skills associated with digital technologies for } \\
\text { the } 21 \text { st century. }\end{array}$ \\
\hline & $\begin{array}{l}\text { 35. I only practice electronic commerce for goods that I cannot buy from or find in the } \\
\text { market. }\end{array}$ \\
\hline \multirow{6}{*}{$\begin{array}{l}\text { Protect Yourself/ } \\
\text { Protect Others } \\
\quad(\mathrm{N}=11)\end{array}$} & 36. I always back up important data in a safe or external hard drive. \\
\hline & 37. I always protect personal and important information in password-protected files. \\
\hline & 38. I regularly change my passwords to protect my privacy. \\
\hline & 39. I always read the privacy statement before installing new software. \\
\hline & $\begin{array}{l}\text { 40. I always do quick maintenance to remove unnecessary files and programs from my } \\
\text { computer. }\end{array}$ \\
\hline & 41. I have been taught about the possible threats when using new digital technologies. \\
\hline \multirow{5}{*}{$\begin{array}{c}\text {-Rights \& } \\
\text { Responsibility } \\
\text { - Safety (Security) } \\
\text { - Health \& } \\
\text { Welfare }\end{array}$} & 42. I always visit trusted and harm-free websites. \\
\hline & $\begin{array}{l}\text { 43. When I notice strange things happening to my computer, I take it right away to the } \\
\text { maintenance center. }\end{array}$ \\
\hline & $\begin{array}{l}\text { 44. I always find support when I encounter issues in using new digital technologies in my } \\
\text { learning activities. }\end{array}$ \\
\hline & $\begin{array}{l}\text { 45. I have been trained on how to integrate new digital technologies in my future teaching } \\
\text { activities. }\end{array}$ \\
\hline & 46. I do not open any unknown or untrusted files. \\
\hline
\end{tabular}

\section{Copyrights}

Copyright for this article is retained by the author(s), with first publication rights granted to the journal.

This is an open-access article distributed under the terms and conditions of the Creative Commons Attribution license (http://creativecommons.org/licenses/by/3.0/). 